\title{
TINGKAT KEPUASAN KONSUMEN TERHADAP RESTORAN HAPPY COW STEAK BOGOR JAWA BARAT
}

\author{
Ayumi Fitriani Gunawan'), dan Wahyu Budi Priatna' ${ }^{2)}$ \\ ${ }^{1,2)}$ Departemen Agribisnis, Fakultas Ekonomi dan Manajemen, Institut Pertanian Bogor \\ 1)ayumigunawan@gmail.com
}

\begin{abstract}
Happy Cow Steak is a restaurant in Bogor which offers western menu with steak as its main product. The aim of this research was to find out the characteristic of Happy Cow Steak's consumers, buying decision process, and consumer satisfaction. There were 90 respondents participating in this reserach. The methods used in this study were descriptive analysis, Importance Performance Analysis (IPA), and Customer Satisfaction Index (CSI). The research showed that the majority of consumers who visited Happy Cow Steak Restaurant were women, 21-30 years old, income between Rp 500.000 to Rp 1.499.999 per month, bachelors and senior high school, graduate students, not married, and lived in Bogor. There were five stages which the happy cow steak consumers had in their buying decision making process, i.e. need recognition, information search, alternative evaluation, purchase decision, and post-purchase behavior. Importance Performance Analysis (IPA) showed that the steak cutlery availability, restaurant cleanness, and restaurant comfort were the priority to be improved to meet customer satisfaction. Based on Customer Satisfaction Index (CSI) test, consumer satisfaction level of Happy Cow Steak Restaurant was 71, 94 percent implying that the customers were satisfied.
\end{abstract}

Keyword(s): CSI, Happy Cow Steak, IPA, Satisfaction, Consumer Behavior

\begin{abstract}
ABSTRAK
Happy Cow Steak merupakan salah satu restoran yang berada di Bogor yang menawarkan berbagai macam menu western dengan steak sebagai menu utama mereka. Tujuan dari penelitian ini adalah untuk mengetahui karaktersitk konsumen, proses keputusan pembelian konsumen, dan kepuasan konsumen restoran Happy Cow Steak. Jumlah responden dalam penelitian adalah 90 responden. Metode analisis yang digunakan pada penelitian ini adalah analisis deskriptif, Importance Performance Analysis (IPA), dan Customer Satisfaction Analysis (CSI). Berdasarkan hasil penelitian dapat diketahui bahwa mayoritas konsumen restoran Happy Cow Steak adalah perempuan, dengan rentang usia 21-30 tahun, pendapatan per bulan sebesar Rp 500.000 hingga $\mathrm{Rp} 1.499 .999$, memiliki pendidikan terakhir sekolah menengah atas dan sarjana, bekerja sebagai pelajar/mahahsiswa, belum menikah, dan berdomisili di Bogor. Konsumen restoran Happy Cow Steak melalui lima tahapan dalam menjalani proses keputusan pembelian mereka, yaitu tahap pengenalan kebutuhan, pencarian informasi, evaluasi alternatif, pembelian dan pasca pemebelian. Hasil Importance Performance Analysis (IPA) menunjukkan bahwa atribut peralatan makan steak, kebersihan dan kenyaman restoran merupakan prioritas utama dalam perbaikan kinerja untuk meningkatkan kepuasan konsumen. Nilai Customer Satisfaction Analysis (CSI) sebesar 71,94 persen, yang menandakan bahwa sebagian besar konsumen restoran Happy Cow Steak merasa puas.
\end{abstract}

Kata Kunci: CSI, Happy Cow Steak, IPA, Kepuasan, Perilaku Konsumen 


\section{PENDAHULUAN}

Bogor merupakan salah satu kota besar yang berada di provinsi Jawa Barat. Kota Bogor memiliki pertumbuhan ekonomi yang mengalami peningkatan setiap tahunnya. Peningkatan ini dapat dilihat melalui data Produk Domestik Regional Bruto (PDRB) yang dapat menunjukkan pendapatan di suatu daerah. Tabel 1 menunjukkan bahwa PDRB Kota bogor pada tahun 2009-2012 mengalami peningkatan setiap tahunnya.

Badan Pusat Statistika (BPS) Kota Bogor mencatat bahwa sumbangan terbesar PDRB Kota Bogor berasal dari sektor perdagangan, hotel, dan restoran. Kontribusi sektor ini setiap tahunnya mengalami peningkatan rata-rata sebesar 8,625 persen. Baye (2002) menyatakan bahwa adanya peningkatan pendapatan akan mempengaruhi konsumsi seseorang. Meningkatnya PDRB Kota Bogor terutama pada sektor perdagangan, hotel, dan restoran, juga mempengaruhi konsumsi masyarakat Kota Bogor. Hal ini ditunjukkan oleh peningkatan jumlah restoran yang berada di Kota Bogor. Restoran termasuk salah satu produk agribisnis yang merupakan pengusahaan pengelolaan hasil pertanian. Restoran berada pada subsistem hilir dimana hasil pertanian diolah sedemikian rupa sehingga menjadi makanan jadi yang kemudian di jual dalam toko.

Tabel 2 menunjukkan adanya peningkatan jumlah restoran di Kota Bogor setiap tahunnya. Hal ini mengindikasikan adanya perubahan pola konsumsi masyarakat Kota Bogor yang memiliki peningkatan untuk mengkonsumsi makan di luar rumah. Akibat perubahan pola konsumsi masyarakat ini, permintaan akan adanya restoran sebagai pemenuhan kebutuhan konsumsi pun mengalami peningkatan.

Pelaku usaha melihat tren peningkatan permintaan restoran sebagai suatu potensi untuk mengembangkan usaha di bidang kuliner. Restoran melakukan diferensiasi produk dan layanan dengan mengusung tema dan konsep yang berbeda-beda. Berdasarkan jenis hidangan yang disajikan, restoran di Kota Bogor dapat dikelompokan ke dalam lima kategori yaitu restoran Indonesia, tradisional, international, oriental, dan kontinental (Dinas Kebudayaan dan Pariwisata Kota Bogor, 2012).

Dinas Kebudayaan dan Pariwisata Kota Bogor juga mencatat bahwa restoran berjenis kontinental cenderung mengalami penurunan jumlah dalam lima tahun terakhir (2008-2012). Hal ini dapat mengindikasikan adanya tingkat per-

Tabel 1. Presentase Pertumbuhan Produk Domestik Regional Bogor (PDRB) Sektor Perdagangan, Hotel, dan Restoran Tahun 2010-2013 Kota Bogor

\begin{tabular}{ccc}
\hline Tahun & Jumlah (Juta Rupiah) & Pertumbuhan (\%) \\
\hline 2009 & 4528576.95 & - \\
2010 & 5147429.56 & 13.66 \\
2011 & 5675588.90 & 10.24 \\
2012 & 6276208.33 & 8.62 \\
\hline
\end{tabular}

Sumber: Badan Pusat Statistika Kota Bogor (2013) 
Tabel 2. Jumlah Restoran yang Berada di Kota Bogor Tahun 2008-2012

\begin{tabular}{cc}
\hline Tahun & Jumlah Restoran (Unit) \\
\hline 2008 & 602174 \\
2009 & 739349 \\
2010 & 826740 \\
2011 & 882214 \\
2012 & 955173 \\
\hline
\end{tabular}

Sumber: Badan Pusat Statistik Kota Bogor (2013)

saingan yang sangat kompetitif antar restoran kontinental sehingga mengalami tren menurun dalam kurun waktu lima tahun terakhir. Walaupun mengalami penurunan, restoran kontinental telah tersebar di Kota Bogor dengan menawarkan menu utama yang berbeda-beda.

Happy Cow Steak merupakan salah satu restoran berjenis kontinental yang berada di Kota Bogor. Restoran ini menawarkan berbagai jenis hidangan western dengan steak sebagai menu utama. Lokasi Happy Cow Steak yang berada di daerah Bangbarung membuat restoran ini berada pada persaingan yang kompetitif. Lokasi ini juga menjadi tempat kuliner bagi masyarakat Kota Bogor maupun pengunjung yang berdomisili di luar Bogor. Sepanjang daerah Bangbarung ini terdapat lebih dari sepuluh restoran dengan berbagai keunikan produknya tersendiri. Restoranrestoran tersebut dapat menjadi pesaing Happy Cow Steak, baik restoran yang sudah terlebih dahulu berdiri dan memiliki pangsa pasar yang besar, maupun restoran baru yang memiliki potensi.

Kendala lain yang dihadapi oleh Restoran Happy Cow Steak adalah target penjualan per bulan yang masih belum tercapai. Penjualan Restoran Happy Cow Steak pada bulan Juni hingga bulan
November berturut-turut adalah $\mathrm{Rp}$ 66.034.500, $\quad \mathrm{Rp} \quad 57.256 .000, \quad \mathrm{Rp}$ 64.723.000, Rp 52.451.000, Rp 54.683.000, dan Rp 64.443.000. Penjualan tersebut berada di bawah target penjualan restoran yaitu sebesar Rp 150.000.000 per bulannya. Target ini ditetapkan berdasarkan kapasitas kursi yang dapat menampung konsumen dalam sehari. Kapasitas kursi yang dapat menampung konsumen tersebut dihitung berdasarkan jumlah kursi yang tersedia di restoran, baik di ruangan indoor maupun outdoor, dengan asumsi bahwa konsumen yang berkunjung padat dan tidak memerlukan jeda yang lama antara konsumen yang pergi dan konsumen yang datang. Namun, semenjak restoran ini didirikan (Mei 2011) hingga saat ini (Januari 2014), target penjualan tersebut belum pernah tercapai.

Restoran Happy Cow Steak juga menerima keluhan dari para konsumennya. Pemilik mengatakan bahwa pihaknya menerima beberapa keluhan dari konsumen restoran Happy Cow Steak baik secara eksplisit maupun implisit. Beberapa konsumen mengutarakan keluhannya secara langsung kepada pihak restoran, sementara beberapa lainnya menunjukkan keluhan dari sikapnya. Adanya kendala-kendala tersebut mem- 
buat pihak manajemen Happy Cow Steak perlu menganalisis perilaku konsumennya, agar dapat merumuskan strategi pemasaran berdasarkan karaktersitik konsumen, memahami proses keputusan pembelian konsumen, dan mengetahui kebutuhan konsumen sehingga dapat meningkatkan kepuasan konsumen. Berdasarkan uraian tersebut maka pertanyaannya adalah bagaimana karakteristik konsumen Restoran Happy Cow Steak? Bagaimana proses pengambilan keputusan pembelian konsumen Happy Cow Steak? Bagaimana tingkat kepuasan konsumen Restoran Happy Cow Steak? Penelitian ini berusaha untuk menjawab permasalahan tersebut sehingga memiliki tujuan mengidentifikasi karakteristik konsumen Happy Cow Steak, menganalisis proses pengambilan keputusan pembelian konsumen Happy Cow Steak, dan menganalisis tingkat kepuasan konsumen di Restoran Happy Cow Steak.

\section{KERANGKA PEMIKIRAN}

\section{Proses Pengambilan Keputusan Pembelian Konsumen}

Proses pembelian yang spesifik menurut Kotler dan Keller (1997) terdiri dari urutan kejadian yaitu mengenali kebutuhan, pencarian informasi, evaluasi alternatif, keputusan pembelian, perilaku pasca pembelian.

\section{Pengenalan Kebutuhan}

Masalah merupakan hasil dari adanya perbedaan antara keadaan yang diinginkan konsumen dan keadaan yang sebenarnya dihadapi. Konsumen termotivasi untuk mengatasi perbedaan tersebut dan karena itu mereka melakukan proses pembelian.

\section{Pencarian Informasi}

Pada saat konsumen merasakan adanya masalah, dan kemudian mereka mengenali masalah tersebut sebagai kebutuhan mereka yang belum terpenuhi, maka langkah yang akan dilakukan adalah mencari informasi tentang produk dan layanan yang dapat memecahkan kebutuhan tersebut. Konsumen melakukan pencarian informasi baik secara internal (memori) maupun eksternal.

3. Evaluasi Alternatif

Pada tahap ini konsumen membandingkan merek dan produk yang dipertimbangkan dalam memenuhi kebutuhan mereka. Model multiatribut menjelaskan bagaimana sikap konsumen mengevaluasi alternatif-alternatif pada berbagai atribut dan sejumlah strategi yang dapat digunakan untuk mempengaruhi sikap, dan cara konsumen menerapkan kriteria untuk membuat keputusan.

4. Keputusan Pembelian

Pada beberapa kasus, terkadang niat pembelian tidak mengakibatkan pembelian aktual. Proses internal psikologis yang relevan dengan tahap pembelian ini adalah integrasi.

5. Pasca Pembelian

Tahap pasca pembelian merupakan proses evaluasi terhadap pembelian yang dilakukan oleh konsumen. Konsumen membandingkan kinerja produk dengan harapan mereka. Apabila produk memenuhi harapan konsumen, maka mereka akan bereaksi positif dan akan melakukan pembelian berulang maupun mengajak konsumen baru. Namun apabila kinerja tidak 
memenuhi harapan, maka konsumen akan bereaksi negatif.

\section{Bauran Pemasaran}

Kotler dan Keller (1997) mengemukakan definisi bauran pemasaran sebagai sekumpulan alat pemasaran yang dapat digunakan oleh pemasaran yang dapat digunakan oleh perusahaan untuk mencapai tujuan pemasarannya dalam pasar sasaran. Menurut Zeithaml dan Bitner (2001) dalam Hurriyati (2005), konsep bauran pemasaran tradisional terdiri dari product, price, place dan promotion, namun, untuk pemasaran jasa perlu bauran pemasaran yang diperluas yaitu dengan menambahkan people, physical evidence, dan process. Selanjutnya Hurriyati (2005) menjabarkan bauran pemasaran sebagai berikut:

\section{Product (Produk)}

Produk menurut Kotler dan Keller (1997) merupakan segala sesuatu yang dapat ditawarkan produsen untuk diperhatikan, diminta, dicari, dibeli, digunakan atau dikonsumsi pasar sebagai pemenuhan kebutuhan atau keinginan pasar yang bersangkutan. Nilai sebuah produk ditetapkan oleh pembeli berdasarkan manfaat yang akan mereka terima dari produk tersebut.

\section{Price (Harga)}

Harga merupakan atribut produk atau jasa yang dinyatakan dengan uang (Schiffman, 2008). Penetuan harga merupakan titik kritis dalam bauran pemasaran karena harga menentukan pendapatan dari suatu bisnis. Strategi penentuan harga dalam suatu perusahaan dapat menggunakan penentu- an tarif premium pada saat permintaan tinggi dan tarif diskon pada saat permintaan turun.

3. Place (Lokasi)

Lokasi dalam industri jasa dapat diartikan sebagai tempat pelayanan jasa. Lokasi berhubungan dengan keputusan yang dibuat oleh perusahaan mengenai dimana operasi dan stafnya akan ditempatkan, yang paling penting dari lokasi adalah tipe-tipe interaksi yang terlibat. Lokasi sangat berpengaruh terhadap keinginan konsumen untuk berkunjung dan berbelanja, sehingga seorang pengusaha akan selalu berusaha mencari lokasi strategis yang mudah dilihat dan dijangkau oleh konsumen (Sumarwan, 2002).

4. Promotion (Promosi)

Pada hakikatnya menurut Buchari Alma (2000), promosi suatu bentuk komunikasi pemasaran yang merupakan aktivitas pemasaran yang berusaha menyebarkan informasi, membujuk, dan/atau mengingatkan pasar sasaran atas perusahaan dan produknya agar bersedia menerima, membeli, dan loyal pada produk yang ditawarkan perusahaan yang bersangkutan.

5. People (Orang)

Menurut Zeithaml dan Bitner (2000) orang adalah semua pelaku yang memainkan peranan dalam penyajian jasa sehingga dapat mempengaruhi persepsi pembeli. Elemen-elemennya adalah pegawai perusahaan, konsumen dan konsumen lain dalam lingkungan jasa. Semua sikap dan tindakan karyawan, bahkan cara berpakaian karyawan dan penampilan karyawan mempunyai pengaruh ter- 
hadap persepsi konsumen atau keberhasilan penyampaian jasa.

6. Physical Evidence (Sarana Fisik) Zeithaml dan Bitner (2000) berpendapat bahwa sarana fisik merupakan suatu hal yang secara nyata turut mempengaruhi keputusan konsumen untuk mebeli dan menggunakan produk jasa yang ditawarkan. Unsur-unsur yang termasuk di dalam saran fisik antara lain lingkungan fisik, dalam hal ini bangunan fisik, peralatan, perlengkapan, logo, warna dan barangbarang lainnya yang disatukan dengan servis yang diberikan seperti tiket, sampul, label, dan lainnya.

7. Process (Proses)

Menurut Zeithaml dan Bitner (2000) proses adalah semua prosedur aktual, mekanisme, dan aliran aktivitas yang digunakan untuk menyampaikan jasa. Elemen proses ini mempunyai arti suatu upaya perusahaan dalam menjalankan dan melaksanakan aktivitasnya untuk memenuhi kebutuhan dan keinginan konsumennya.

\section{Kepuasan Konsumen}

Kotler dan Amstrong (1999) mengatakan bahwa kepuasan konsumen merupakan tingkat perasaan seseorang setelah membandingkan antara kinerja produk yang ia rasakan dengan harapannya. Kepuasan juga merupakan hasil yang diperoleh dari evaluasi setelah melakukan pembelian dan mengkonsumsi suatu barang dan jasa (Engel et al, 1994). Konsumen yang telah melakukan konsumsi akan melakukan evaluasi apakah produk/jasa yang dikonsumsi tersebut sesuai dengan apa yang diharapkan atau tidak. Apabila perceived quality sesuai bahkan melebihi expected quality maka akan timbul kepuasan dalam diri konsumen.

Hasan (2013) menjabarkan bahwa etika akan konsumen membeli produk/ jasa dari suatu perusahaan, mereka memiliki harapan tersendiri akan kualitas produk tersebut. Sebelum melakukan pemakaian produk, konsumen terlebih dahulu mengevaluasi kinerja atributatribut produk. Setelah melakukan pemakaian produk, konsumen akan merespon produk secara kognitif, yaitu apakah sesuai maupun tidak sesuai dengan harapannya yang akan muncul sebagai respon emosional. Respon emosional ini akan menghasilkan rasa puas atau tidak puas terhadap kinerja. Respon ini kemudian akan berpengaruh terhadap produk perusahaan.

\section{METODE PENELITIAN}

\section{Jenis Penelitian dan Sumber Data}

Penelitian ini menggunakan metode pendekatan kuantitatif. Berdasarkan teknik pengumpulan data, penelitian ini menggunakan dua macam data, data primer dan data sekunder. Data Primer diperoleh melalui wawancara terstruktur dengan responden, dimana pertanyaanpertanyaan yang diajukan mengacu pada kuesioner yang telah disiapkan. Kuesioner yang diajukan memiliki jawaban yang tertutup dimana konsumen hanya menjawab pada pilihan jawaban yang telah disediakan.

Data sekunder diperoleh melalui berbagai macam sumber-sumber yang dianggap relevan dengan penelitian. Sumber tersebut berupa hasil dari studi literatur 
yaitu skripsi dan jurnal yang relevan dengan topik penelitian. Data juga diperoleh dari berbagai instansi-instansi terkait, seperti Badan Pusat Statistik Bogor, serta Dinas Kebudayaan dan Pariwisata.

\section{Populasi dan Sampel}

Populasi dalam penelitian ini adalah konsumen Happy Cow Steak cabang Bogor yang berumur tujuh belas tahun ke atas yang telah mengunjungi restoran sebelumnya minimal satu kali kunjungan dalam kurun waktu tiga bulan terakhir. Penelitian ini menggunakan sampel, sebab tidak seluruh populasi diambil, melainkan hanya sebagian populasi dari penelitian yang akan digeneralisasikan pada seluruh populasi. Teknik penarikan sampel yang akan digunakan dalam penelitian ini adalah non-probability sampling dikarenakan peneliti tidak mengambil sampel dari populasi tersebut secara adil dengan tidak memberi peluang yang sama kepada setiap anggota untuk terambil menjadi sampel. Sementara metode yang digunakan adalah convenience sampling. Metode ini mengambil sampel yang terdiri dari individu yang paling mudah dijumpai atau diakses dimana hasilnya menunjukkan bukti-bukti yang cukup berlimpah sehingga prosedur pengambilan sampel yang lebih canggih tidak dibutuhkan lagi. Sampel yang digunakan pada penelitian ini adalah 90 responden.

\section{Uji Validitas dan Reliabilitas}

Instrumen, pada penelitian ini adalah kuesioner, dimana kuesioner tersebut dikatakan valid apabila mampu mengukur apa yang diinginkan dan dapat mengungkap data variabel yang diteliti secara tepat. Sedangkan suatu instrumen dikatakan reliabel jika instrumen tersebut digunakan beberapa kali dalam waktu yang berbeda untuk mengukur obyek yang sama akan menghasilkan data yang sama pula. Teknik pengukuran reliabilitas yang digunakan adalah teknik Cronbach. Baik uji validitas maupun uji reliabilitas diuji menggunakan software SPSS 16.0.

Berdasarkan hasil perhitungan, $r$ hitung pada ke-28 atribut lebih besar dibandingkan dengan $r$ tabel. Artinya ke28 artibut tersebut sudah valid dan layak diberikan kepada responden sebagai alat ukur pengambilan data. Untuk pengujian reliabilitas menunjukkan hasil alpha di atas 0,81 sehingga termasuk ke dalam kategori sangat reliabel. Artinya semua atribut sudah konsisten dalam mengukur kepuasan konsumen pada penelitian ini.

\section{Analisis Deskriptif}

Analisis deskriptif dilakukan dengan membuat tabulasi frekuensi sederhana berdasarkan jawaban responden. Karakteristik konsumen Restoran Happy Cow Steak dapat terlihat dari segi usia, domisili, status menikah, jenis kelamin, pendidikan, pendapatan, serta pekerjaan. Analisis ini juga dapat digunakan untuk mengetahui proses pengambilan keputusan pembelian berdasarkan lima tahapan, yaitu; pengenalan kebutuhan, pencarian informasi, evaluasi alternatif, pembelian, serta perilaku pasca pembelian.

\section{Important Performance Analysis (IPA)}

Importance Performance Analysis (IPA) merupakan suatu teknik yang di- 
gunakan untuk mengukur tingkat kepentingan dan tingkat kinerja atribut. Penilaian tingkat kepentingan menilai seberapa pentingnya atribut-atribut tersebut menurut sudut pandang konsumen. Sedangkan penilaian tingkat kinerja merupakan penilaian konsumen terhadap kinerja restoran pada atribut-atribut yang ada, apakah kinerja tersebut sesuai dengan harapan konsumen, melampaui, atau bahkan tidak memenuhi harap konsumen. penilaian tingkat kepentingan maupun tingkat kinerja, menggunakan nilai skor skala 5 tingkat (likert). Angka 1 untuk intensitas yang terendah, sementara angka 5 untuk intensitas tertinggi.

Hasil perhitungan digambarkan melalui diagram kartesius yang terdiri dari empat kuadran. Masing-masing kuadran menunjukkan keadaan yang berbeda:

1. Kuadran I (Prioritas Tinggi)

Memuat atribut-atribut yang dianggap penting oleh konsumen namun pada kenyataanya kinerja yang dilakukan manajemen Happy Cow Steak terhadap atribut-atribut tersebut belum sesuai dengan apa yang diharapkan konsumen.

2. Kuadran II (Pertahankan Prestasi)

Memuat atribut-atribut yang dianggap penting oleh konsumen dan realisasi kinerja yang dilakukan manajemen Happy Cow Steak terhadap atributatribut tersebut sesuai dengan apa yang diharapkan oleh konsumen.

3. Kuadran III (Prioritas Rendah)

Pada Kuadran III memuat atributatribut yang dianggap kurang penting oleh konsumen dan pada kenyataanya kinerja pihak Happy Cow Steak terhadap atribut-atribut tersebut pun tidak teralu istimewa.

4. Kuadran IV (Berlebihan) memuat atribut-atribut yang dianggap kurang penting oleh konsumen, namun pada kenyataanya kinerja yang dilakukan pihak Happy Cow Steak sangat baik sekali sehingga dinilai berlebihan.

\section{Customer Satisfaction Index (CSI)}

Model Costumer Satisfaction Index (CSI) atau Indeks Kepuasan Pelanggan digunakan untuk menentukan tingkat kepuasan pelanggan secara menyeluruh dengan pendekatan yang mempertimbangkan tingkat kepentingan dari atributatribut yang diukur. Metode pengukuran CSI ini terdiri dari empat tahap perhitungan yaitu Weight Factor (WF), Weighted Score (WS), Weight Average Total (WAT), dan Customer Satisfaction Index.

\section{KARAKTERISTIK KONSUMEN}

Hasil penelitian menunjukkan bahwa responden berjenis kelamin wanita berkisar hingga 61,10 persen, sedangkan responden pria hanya berkisar 38,90 persen. Hal ini sesuai dengan penelitian terdahulu yang menyatakan bahwa pengunjung restoran mayoritas berjenis kelamin wanita (Andreani F et al., 2010; Ariffin HM et al., 2010; Gunawan, 2013; Tan Q et al., 2014; Fadhila, 2010). Mangkunegara (2002) menyatakan bahwa pembeli wanita lebih banyak tertarik pada gejala mode dan mementingkan status sosial dalam pembelajaannya, sehingga sangat wajar apabila responden wanita lebih banyak melakukan pem- 
belian dibandingkan dengan pria. Pada segi rentang usia, responden terbanyak berada pada rentang usia 21-30 tahun (71,10 persen), diikuti dengan rentang usia 17-20 tahun (13,30 persen), 31-40 tahun (7,80 persen), 41-50 tahun $(5,60$ persen), dan $>50$ tahun (2,20 persen). Sesuai dengan penelitian yang telah dilakukan sebelumnya bahwa mayoritas konsumen yang mengunjungi restoran berada pada rentang usia 20-30 tahun (Andreani F et al., 2010; Ariffin HM et al., 2010; Gunawan, 2013; Tan Q et al., 2014; Fadhila, 2010; Fitriani, 2012; Harianto \& Subagio, 2013; Irawan \& Japarianto, 2013).

Mayoritas responden memiliki pendidikan terakhir SMA (38.90 persen), S1 (37,80 persen), diploma (10 persen), S2 (5,60 persen), SMP (4,40 persen), S3 (2,20 persen), dan lainnya (1,1 persen). Sementara sebagian besar responden berprofesi sebagai pelajar/mahasiswa (52,20 persen), pegawai swasta $(22,20$ persen), pegawai negeri sipil dan pekerjaan lainnya masing-masing 8,90 persen, wiraswasta (4,40 persen), dan ibu rumah tangga (3,30 persen). Hasil tersebut dipengaruhi oleh letak restoran Happy Cow Steak yang berada diantara beberapa sekolah menengah atas (SMA), perguruan tinggi, dan juga perkantoran swasta. Sebagian besar responden memiliki pendapatan atau uang saku rata-rata sebulan berkisar Rp 500.000 - Rp 1.499 .999 (34.40 persen), Rp 1.500.000 Rp 2.499.999 (23,30 persen), Rp 2.500.000 - Rp 3.499.999 (17,80 persen), Rp 3.500.000 - Rp $4.500 .000 \quad(12,20$ persen), >Rp 4.000 .000 (7,80 persen), dan $<$ Rp 500.000 (4,40 persen). Responden tidak hanya berasal dari Bogor $(80,00$ persen), tetapi juga berasal dari luar Bogor (20,00 persen). Responden yang berasal dari luar Bogor seperti Depok, Jakarta, dan Pamulang. Mayoritas responden berstatus belum menikah (97,06 persen), sedangakan yang sudah menikah hanya berkisar 2,94 persen

\section{PROSES KEPUTUSAN PEMBELIAN}

Proses keputusan pembelian menunjukkan perilaku konsumen dalam melakukan pembelian dimulai dari tahap pengenalan produk, pencarian informasi, evaluasi alternatif, pembelian, dan pasca pembelian. Pada tahap awal yaitu pengenalan kebutuhan, mayoritas konsumen mengkonsumsi makanan di luar rumah dalam sebulan sebanyak lebih dari 7 kali (53,3 persen), diikuti dengan 5-7 kali (27,8 persen), dan 1-4 kali (18,9 persen). Alasan utama responden dalam mengkonsumsi makanan di luar rumah adalah karena memiliki hobi akan kuliner (45,67 persen), tidak sempat memasak di rumah (24,4), alasan lainnya (12,2 persen), tuntutan gaya hidup dan mencari menu yang khas (6,7 persen), dan mencari tempat yang nyaman (4,4 persen). Sedangkan manfaat yang mereka rasakan dari mengkonsumsi makan di luar rumah adalah sebagai pemenuhan hobi mereka akan kuliner (35,60 persen), sebagai tempat berkumpul keluarga (28 persen), menghilangkan rasa lapar (20 persen), menghemat waktu $(7,8$ persen) sebagai makanan selingan (6,4 persen) dan lainnya (2,2 persen).

Pada tahap pencarian informasi, mayoritas responden mendapatkan informasi mengenai restoran Happy Cow Steak 
melalui teman/kerabat $(58,90$ persen $)$, diikuti oleh diri sendiri (16,70 persen), anggota keluarga (12,20 persen), media sosial (11,10 persen), dan lainnya $(1,1$ persen). Berdasarkan sumber informasi, yang menjadi fokus utama dari restoran Happy Cow Steak adalah cita rasa $(44,40$ persen), jenis produk yang unik $(22,20$ persen), harga yang ditawarkan (14 persen), lokasi yang strategis $(8,67$ persen), lainnya (4 persen), dan kenyaman tempat (3,3 persen).

Tahap selanjutnya adalah evaluasi alternatif. Hal utama yang menjadi pertimbangan awal responden ketika melakukan pembelian di suatu restoran diantaranya, harga yang relatif terjangkau (23,33 persen), lokasi yang strategis $(18,9$ persen), dan rasa penasaran/hanya ingin mencoba (15,6 persen). Sementara, faktor-faktor yang menjadi pertimbangan awal responden dalam melakukan pembelian di restoran Happy Cow Steak diantaranya, cita rasa produk $(15,35$ persen) dan harga yang relatif terjangkau (15,35 persen), kesesuaian antara harga dengan porsi dan kualitas steak yang disajikan serta lokasi yang strategis masing-masing sebanyak 13,95 persen.

Tahap keempat yaitu pembelian. Mayoritas responden melakukan kunjungan yang bersifat terencana (72,20 persen), sedangkan sisanya adalah tidak terencana (27,80 persen). Sebagian besar responden melakukan pembelian menu steak di restoran Happy Cow Steak dipengaruhi oleh teman/kerabat $(48,90$ persen) mereka, kemudian diikuti berdasarkan insiatif sendiri (30,00 persen), pengaruh keluarga (16,70 persen), pengaruh promosi di media sosial $(2,2$ persen), dan alasan lainnya (2,2 persen). Mayoritas responden melakukan kunjungan secara tidak menentu $(50,00$ persen), namun beberapa responden mengunjungi secara rutin pada akhir pekan (26,70 persen), hari kerja (15,50 persen), hari libur nasional (7,80 persen). Waktu favorit responden dalam melakukan kunjungan secara berturut-turut adalah pada sore hari (Pukul 15.01 19.00) sebanyak 52,20 persen, malam hari (Pukul 19.01 - 22.00) sebanyak 26,70 persen, dan siang hari (Pukul 11.00 15.00) sebanyak 21,1 persen.

Tahap yang terakhir adalah pasca pembelian. Mayoritas responden secara keseluruhan merasa puas telah mengunjungi restoran happy cow steak $(52,20$ persen), sementara (31.1 persen) merasa tidak puas, dan sisanya (16,7 persen) netral. Sebanyak 91,10 persen responden juga menyatakan akan melakukan kunjungan kembali ke Restoran Happy Cow Steak, dan 8,90 persen responden yang menyatakan tidak akan melakukan kunjungan kembali.

\section{TINGKAT KEPUASAN KONSUMEN Important Performance Analysis (IPA)}

Pihak restoran perlu meningkatkan kepuasan konsumen yang dimilikinya hingga hasil yang optimum agar mendatangkan profit yang lebih besar bagi restoran. Peningkatan kepuasan ini dapat diperoleh apabila pihak restoran melakukan perbaikan dengan cara meningkatkan tingkat kepentingan dan tingkat kinerja. Namun, peningkatan kepentingan konsumen dinilai sangat sulit untuk dilakukan. Hal ini dikarenakan tingkat kepentingan tergantung pada persepsi 
masing-masing konsumen secara individu yang sulit untuk dirubah. Oleh karenanya, pada penelitian ini hal yang akan ditingkatkan untuk mendapatkan tingkat kepuasan yang optimal adalah kinerja restoran. Peningkatan kinerja restoran dapat dilakukan dengan cara meningkatkan kinerja atribut-atribut yang berada di Restoran Happy Cow Steak. Restoran memiliki keterbatasan dalam sumberdaya manusia dan sumber daya modal, sehingga tidak semua atribut dapat diperbaiki. Keterbatasan tersebut mendorong restoran untuk memprioritaskan apa yang menjadi hal penting dalam melakukan perbaikan kinerja. Atribut yang diprioritaskan adalah atribut yang memiliki tingkat kepentingan yang tinggi bagi konsumen namun pada pelaksanaannya, kinerja pada atribut tersebut kurang baik. Atribut tersebut dikelompokkan pada kuadran I dalam scatterplot, yang ditunjukkan pada Gambar 1.

Atribut-atribut tersebut dianggap penting oleh konsumen namun pada kenyataanya kinerja yang dilakukan manajemen Happy Cow Steak terhadap atributatribut tersebut belum sesuai dengan apa yang diharapkan konsumen sehingga menghasilkan ketidakpuasan dalam diri konsumen.

Sebagai restoran yang menawarkan steak sebagai menu utamanya, peralatan makan merupakan atribut yang perlu diperhatikan oleh pihak restoran. Mayoritas konsumen mengeluhkan peralatan makan steak mereka yang tidak berfungsi dengan baik, seperti kesulitan dalam memotong steak maupun mata pisau yang terlepas dari gagangnya. Selain itu, konsumen pun menilai tidak seragamnya alat makan steak yang disediakan oleh pihak restoran, ada pisau dengan kualitas prima adapula pisau yang ringkih.

Kebersihan merupakan salah satu faktor vital bagi usaha yang bergerak dalam bidang makanan, terutama restoran. Kebersihan restoran juga dapat meningkatkan selera makan konsumen, Sebaliknya, apabila kebersihan restoran tidak terjaga maka konsumen dapat kehilangan selera makan walaupun cita rasa yang ditawarkan sangat baik. Restoran Happy Cow Steak memiliki jumlah karyawan yang terbatas. Ketika restoran memasuki waktu padat pengunjung, para karyawan sibuk melayani pengunjung dan cenderung tidak memperhatikan kebersihan restoran. Kursi yang dibiarkan berantakan setelah konsumen pergi, banyaknya noda dan debu yang dapat terlihat di lantai restoran, serta beberapa penataan letak yang dibiarkan tidak teratur sehingga kesan "tidak menjaga kebersihan" timbul.

Selain kebersihan, kenyamanan dalam restoran pun menjadi hal yang juga perlu diperhatikan. Restoran kini tidak hanya sebagai tempat untuk menyantap hidangan. Restoran telah berkembang sebagai tempat untuk berkumpul bersama teman/kerabat atau keluarga. Konsumen membutuhkan kenyamanan pada restoran, baik sebagai tempat untuk menyantap hidangan maupun tempat untuk berkumpul bersama. Konsumen menilai kenyamanan saat berada didalam Restoran Happy Cow Steak dapat dikategorikan kurang baik. Mayoritas konsumen mengeluhkan sirkulasi udara yang buruk pada ruangan indoor restoran. Lokasi dapur Restoran Happy Cow Steak yang berada tepat di depan ruangan indoor 


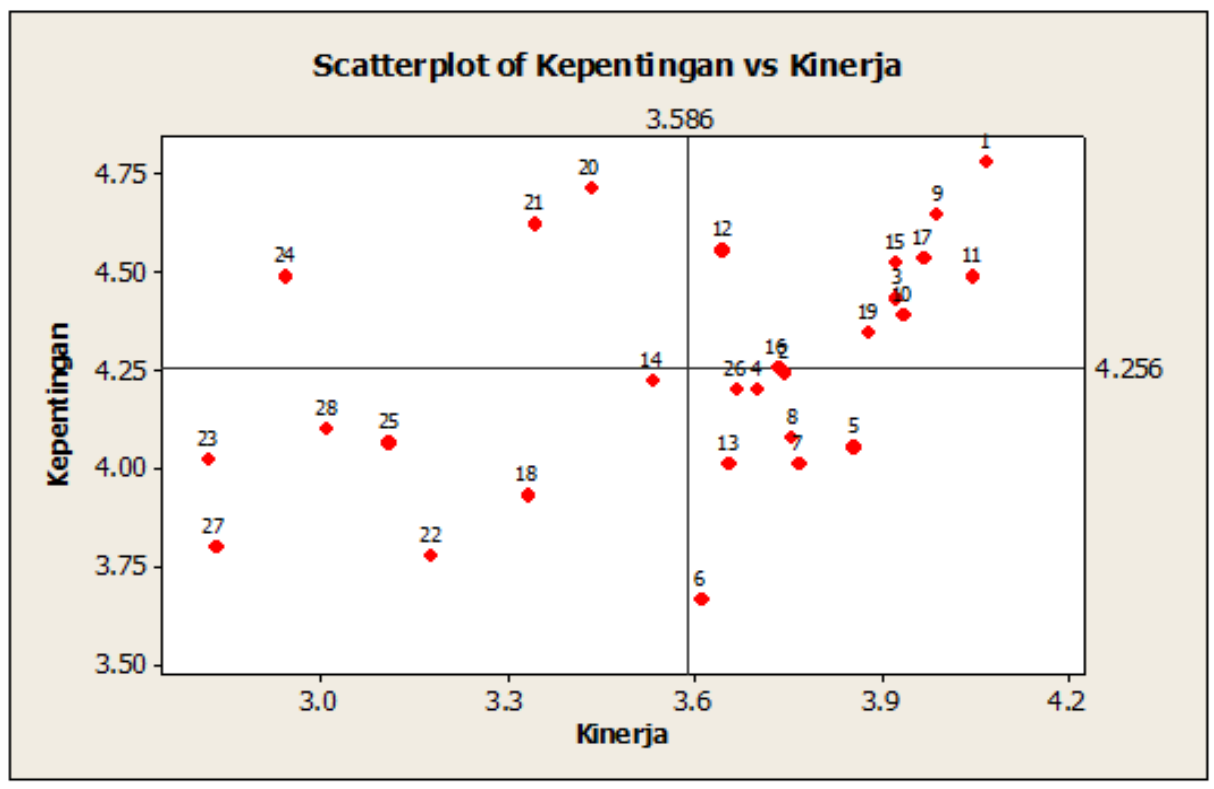

Keterangan:

\section{Kuadran I}

20. Kebersihan restoran

21. Kenyamanan restoran

24. Ketersediaan peralatan makan

\section{Kuadran II}

1. Cita rasa produk

3. Porsi steak yang pas

9. Tingkat kesegaran steak

10. Harga yang terjangkau

11. Kesesuaian antara harga dan porsi

12. Kecepatan dalam pelayanan penyajian

15. Keramahan pramusaji

17. Kesigapan pramusaji dalam memenuhi pesanan

19. Lokasi yang strategis
Kuadran III
14. Kesigapan dalam menghadapi keluhan
18. Penampilan pramusaji
22. Desain interior restoran
23. Ketersediaan dan kebersihan toilet
25. Tampilan restoran
27. Papan nama
28. Promosi melalui media sosial

\section{Kuadran IV}

2. Tampilan pada penyajian

4. Aroma yang menggugah selera

5. Variasi menu steak

6. Variasi menu selain steak

7. Variasi Saus pada Steak

8. Ukuran steak

13. Kecepatan melakukan transaksi

16. Pengetahuan pramusaji

26. Fasilitas yang tersedia

\section{Gambar 1. Diagram Kartesius Kepentingan VS Kinerja}

restoran membuat asap yang ditimbulkan ketika proses memanggang steak berlangsung masuk ke dalam ruangan indoor restoran. Hal ini diperparah dengan fasilitas pendingin ruangan yang tidak optimal menyebabkan sirkulasi ruang indoor restoran dinilai cukup menyesakkan. Hal ini sesuai dengan penelitian terdahulu, dimana kuadran I terdiri atas atribut kualitas layanan (Fadhila 2010; Harianto \& Subagio, 2013; Istianto \& Tyra, 2011; Ryu \& Han, 2011; Tan et al., 2014).

Perbaikan terhadap ketiga atribut tersebut dapat berpengaruh terhadap peningkatan kepuasan konsumen Restoran 
Happy Cow Steak, sehingga penting bagi pihak restoran untuk menindaklanjuti kekurangan pada ketiga atribut tersebut dengan melakukan perbaikan yang dibutuhkan. Pihak restoran perlu mengganti peralatan makan steak, terutama pisau, yang sudah tidak layak untuk dipakai. Penting pula bagi pihak restoran untuk menyamaratakan kualitas pisau menjadi kualitas prima secara keseluruhan sehingga tidak terdapat kesenjangan kepuasan pada konsumen saat menggunakan pisau untuk memotong daging.

Pihak restoran mengakui bahwa mereka telah melakukan penanggulangan dalam memperbaiki sirkulasi udara dengan menaikkan PK $A C$. Namun hal tersebut tidak menyelesaikan masalah karena terlalu banyaknya asap yang masuk ke dalam ruangan. Oleh karenanya dalam menanggulangi sistem sirkulasi udara yang cukup buruk yang dapat mengganggu kenyaman konsumen Restoran Happy Cow Steak, diperlukan alternatif lain. Salah satunya adalah memberikan tambahan exhaust fan dalam ruangan indoor restoran disamping $A C$ agar mampu menyedot asap lebih efektif maupun memperbaiki kualitas exhaust stove yang berfungsi untuk menyedot asap dari kompor ketika proses memasak berlangsung. Sementara untuk menjaga kebersihan restoran, pihak manajemen restoran perlu menerapkan disiplin yang tinggi kepada para karyawannya. Pihak manajemen juga perlu mengingatkan kepada karyawannya bahwa kebersihan merupakan tanggung jawab seluruh karyawan sehingga apabila melihat sesuatu yang kotor atau tidak sesuai dengan tempatnya maka siapapun yang melihatnya perlu membersihkan maupun merpaikan dengan segera. Pembentukan penanggung jawab kebersihan restoran secara harian juga diperlukan agar menimbulkan rasa tanggung jawab dan disiplin sehingga kebersihan restoran terjaga.

Atribut lain yang diperhatikan adalah atribut yang berada pada kuadran II. Kuadran ini memuat atribut-atribut yang dianggap penting oleh konsumen dan realisasi kinerja yang dilakukan manajemen Happy Cow Steak terhadap atributatribut tersebut sesuai dengan apa yang diharapkan oleh konsumen sehingga menimbulkan kepuasan dalam diri konsumen. Hal ini menuntut pihak Happy Cow Steak untuk mempertahankan prestasinya, yang dalam konteks ini mempertahankan kinerjanya yang sudah baik. Terdapat sembilan atribut yang berada pada kuadran II yaitu, cita rasa produk, harga yang terjangkau, tingkat kesegaran steak, porsi steak yang pas, kesigapan pramusaji dalam memenuhi pesanan, kesesuaian antara harga dan porsi yang ditawarkan, lokasi yang strategis, kecepatan dalam penyajian, dan keramahan pramusaji.

Pada implikasinya, pihak restoran hanya perlu berfokus pada atribut-atribut yang berada pada Kuadran I atau prioritas utama. Hal ini dikarenakan kuadran I memuat atribut yang dianggap penting bagi konsumen, dimana atribut-atribut tersebut berpengaruh terhadap pembentukan kepuasan konsumen, namun pada kenyataannya kinerja yang dilakukan pihak restoran kurang. Perbaikan pada atribut ini akan meningkatkan kepuasan dalam diri konsumen. Atributatribut lain yang berada dalam Kuadran II, 
III, maupun IV bukanlah prioritas bagi pihak restoran. Hal ini dikarenakan pada kuadran III dan IV, atribut-atribut yang termasuk ke dalamnya tidak memiliki tingkat kepentingan yang tinggi bagi konsumen. Artinya, atribut tersebut tidak memberikan pengaruh terhadap kepuasan konsumen. Sedangkan pada kuadran II, memuat atribut-atribut yang dirasakan penting bagi konsumen dan pihak restoran telah melakukan kinerja yang baik terhadapnya, sehingga atributatribut tersebut tidak menjadi prioritas bagi pihak restoran.

Perbaikan yang dilakukan terhadap pihak restoran terhadap atribut-atribut yang berada di kuadran I diharapkan dapat meningkatkan kepuasan konsumen secara keseluruhan. Konsumen yang puas akan mendapatkan pengalaman mengkonsumsi yang positif sehingga mereka akan melakukan pembelian berulang dalam jumlah yang lebih banyak (Bloemer \& Odekerken, 2002; Aminu \& Hartini, 2008). Penjualan yang dilakukan perusahaan pun diharapkan dapat meningkat sehingga dapat mencapai target penjualan yang telah ditetapkan oleh pemilik restoran.

\section{Customer Satisfaction Index (CSI)}

Tingkat kepuasan konsumen penting untuk diketahui oleh pelaku usaha untuk mengukur seberapa puas konsumen terhadap kinerja yang telah mereka lakukan. Kepuasan konsumen juga dapat berpengaruh terhadap kelangsungan suatu usaha. Apabila harapan konsumen lebih besar dibandingkan dengan kinerja suatu perusahaan, maka kepuasan konsumen tidak akan terpenuhi dan konsumen dapat bereaksi negatif. Sebaliknya apabila kinerja lebih tinggi dibandingkan dengan harapan konsumen maka kepuasan terpenuhi dan konsumen akan bereaksi positif. Kepuasan konsumen akan mempengaruhi terjadinya pembelian ulang maupun tidak.

Pada Tabel 3 dapat dilihat bahwa nilai Customer Satisfaction Index (CSI) Restoran Happy Cow Steak adalah sebesar 71,94 persen. Nilai Customer Satisfaction Index (CSI) diperoleh dengan membagi nilai Weighted Score Total dengan skala maksimum (skala lima), yang digunakan dalam penelitian ini, kemudian dikalikan dengan 100 persen maka diperoleh hasil nilai Customer Satisfaction Index (CSI) sebesar 71,94 persen. Hasil penelitian ini berada pada rentang nilai 0,60 - 0,80 atau $66 \%<\mathrm{CS} \leq 80 \%$ yang berarti indeks kepuasan konsumen Restoran Happy Cow Steak sudah termasuk pada kriteria "puas". Namun, yang perlu diperhatikan adalah pada tingkat kepuasan 71,94 persen tersebut, restoran belum bisa mencapai target penjualan yang telah ditetapkan. Oleh karena itu, pihak Restoran Happy Cow Steak perlu melakukan perbaikan terhadap atribut yang memiliki kinerja yang rendah namun memiliki tingkat kepentingan yang tinggi, yaitu atribut yang berada pada kuadran I sebagai priotitas utama. Perbaikan kinerja ini harus dilakukan oleh pihak restoran apabila restoran ingin mendapatakan tingkat kepuasan konsumen secara maksimal. 
Tabel 3. Hasil Perhitungan Indeks Kepuasan terhadap Atribut Happy Cow Steak

\begin{tabular}{|c|c|c|c|c|c|}
\hline No & Atribut & $\begin{array}{l}\text { Rata-rata skor } \\
\text { kepentingan }\end{array}$ & $\begin{array}{l}\text { Rata-rata skor } \\
\text { kinerja }\end{array}$ & $\begin{array}{c}\text { Importance } \\
\text { Weighting } \\
\text { Factor }\end{array}$ & $\begin{array}{l}\text { Weighted } \\
\text { Score }\end{array}$ \\
\hline 1 & Cita rasa steak yang enak & 4.778 & 4.067 & 0.040 & 0.163 \\
\hline 2 & $\begin{array}{l}\text { Tampilan penyajian steak } \\
\text { (platting) }\end{array}$ & 4.244 & 3.744 & 0.036 & 0.133 \\
\hline 3 & Porsi steak yang pas & 4.433 & 3.922 & 0.037 & 0.146 \\
\hline 4 & Aroma yang menggugah selera & 4.200 & 3.700 & 0.035 & 0.130 \\
\hline 5 & $\begin{array}{l}\text { Variasi menu steak yang beragam } \\
\text { dan menarik }\end{array}$ & 4.056 & 3.856 & 0.034 & 0.131 \\
\hline 6 & $\begin{array}{l}\text { Variasi menu selain steak yang } \\
\text { beragam dan menarik }\end{array}$ & 3.667 & 3.611 & 0.031 & 0.111 \\
\hline 7 & $\begin{array}{l}\text { Variasi saos steak beragam dan } \\
\text { menarik }\end{array}$ & 4.011 & 3.767 & 0.034 & 0.127 \\
\hline 8 & $\begin{array}{l}\text { Variasi ukuran steak beragam dan } \\
\text { menarik }\end{array}$ & 4.078 & 3.756 & 0.034 & 0.129 \\
\hline 9 & $\begin{array}{l}\text { Variasi tingkat kematangan steak } \\
\text { beragam dan menarik }\end{array}$ & 4.644 & 3.989 & 0.039 & 0.155 \\
\hline 10 & Kesegaran steak yang disajikan & 4.389 & 3.933 & 0.037 & 0.145 \\
\hline 11 & Harga produk yang ditawarkan & 4.489 & 4.044 & 0.038 & 0.152 \\
\hline 12 & $\begin{array}{l}\text { Kesesuaian antara harga dengan } \\
\text { porsi atau kualitas produk }\end{array}$ & 4.556 & 3.644 & 0.038 & 0.139 \\
\hline 13 & Kemudahan menjangkau lokasi & 4.011 & 3.656 & 0.034 & 0.123 \\
\hline 14 & Kebersihan restoran & 4.222 & 3.533 & 0.035 & 0.125 \\
\hline 15 & Kenyamanan restoran & 4.522 & 3.922 & 0.038 & 0.149 \\
\hline 16 & Kecepatan penyajian & 4.256 & 3.733 & 0.036 & 0.133 \\
\hline 17 & Kecepatan transaksi pembayaran & 4.533 & 3.967 & 0.038 & 0.151 \\
\hline 18 & $\begin{array}{l}\text { Tanggapan terhadap keluhan } \\
\text { konsumen }\end{array}$ & 3.933 & 3.333 & 0.033 & 0.110 \\
\hline 19 & $\begin{array}{l}\text { Keramahan pramusaji terhadap } \\
\text { konsumen }\end{array}$ & 4.344 & 3.878 & 0.036 & 0.141 \\
\hline 20 & $\begin{array}{l}\text { Pengetahuan pramusaji terhadap } \\
\text { menu }\end{array}$ & 4.711 & 3.433 & 0.040 & 0.136 \\
\hline 21 & $\begin{array}{l}\text { Kesigapan pramusaji dalam } \\
\text { memenuhi pesanan }\end{array}$ & 4.622 & 3.344 & 0.039 & 0.130 \\
\hline 22 & Penampilan pramusaji & 3.778 & 3.178 & 0.032 & 0.101 \\
\hline 23 & $\begin{array}{l}\text { Desain interior restoran yang } \\
\text { menarik }\end{array}$ & 4.022 & 2.822 & 0.034 & 0.095 \\
\hline 24 & Kebersihan dan ketersediaan toilet & 4.489 & 2.944 & 0.038 & 0.111 \\
\hline 25 & $\begin{array}{l}\text { Kelengkapan peralatan makan } \\
\text { Steak }\end{array}$ & 4.067 & 3.111 & 0.034 & 0.106 \\
\hline 26 & Tampilan luar restoran & 4.200 & 3.667 & 0.035 & 0.129 \\
\hline 27 & $\begin{array}{l}\text { Ketersediaan faktor entertain } \\
\text { (musik, tv, wi-fi) }\end{array}$ & 3.800 & 2.833 & 0.032 & 0.090 \\
\hline \multirow[t]{3}{*}{28} & $\begin{array}{l}\text { Ketersediaan dan kejelasan papan } \\
\text { nama restoran } \\
\text { Promosi melalui media sosial }\end{array}$ & 4.100 & 3.011 & 0.034 & 0.104 \\
\hline & Total & 119.156 & & & 3.597 \\
\hline & Weighted total score & & & CSI & $71.94 \%$ \\
\hline
\end{tabular}

\section{KESIMPULAN DAN SARAN}

\section{Kesimpulan}

1. Mayoritas konsumen Restoran Happy Cow Steak berjenis kelamin perempuan, rentang usia 21 - 30 tahun, berdomisili di Bogor, dengan status belum menikah, tingkat pendidikan terakhir yang dimiliki adalah Sekolah Menengah Atas (SMA) dan Strata 1 (S1), berprofesi sebagai pelajar/ mahasiswa, serta memiliki pendapat- 
an atau uang saku rata-rata per bulan antara Rp 500.000 - Rp 1.499.999.

2. Mayoritas pengambilan keputusan pembelian konsumen Happy Cow Steak pada tahap pengenalan kebutuhan adalah mereka yang memiliki frekuensi makan di luar rumah lebih dari tujuh kali, dengan alasan kuliner dan manfaat yang dirasakan sebagai alat pemenuhan kebutuhan akan kuliner. Pada tahap pencarian informasi, informasi mengenai Restoran Happy Cow Steak melalui teman/ kerabat mereka, dengan fokus utama adalah cita rasa produk. Tahap evaluasi alternatif, pertimbangan awal konsumen ketika berkunjung ke restoran adalah harga yang terjangkau dan pertimbangan konsumen dalam melakukan pembelian di Restoran Happy Cow Steak adalah harga yang terjangkau serta cita rasa produk. Pada tahap pembelian, sebagian besar konsumen melakukan kunjungan yang bersifat terencana, dengan hari kunjungan yang tidak menentu dan waktu konsumen berkunjung adalah sore hari (pukul 15.01 - 19.00), serta sumber yang paling mempengaruhi pembelian konsumen adalah teman/ kerabat. Tahap pasca pembelian, mayoritas konsumen merasakan kepuasan setelah berkunjung ke restoran Happy Cow Steak dan akan melakukan pembelian kembali.

3. Prioritas perbaikan atribut dilakukan dengan menggunakan Importance Performance Analysis (IPA) pada atribut yang berada pada kuadran I yaitu ketersediaan peralatan makan, kebersihan restoran dan kenyamanan restoran. Ketiga atribut tersebut menjadi prioritas utama untuk diperbaiki dan dtingkatkan kinerjanya agar dapat meningkatkan kepuasan konsumen. Indeks kepuasan konsumen yang diukur dengan Customer Satisfaction Index (CSI) yaitu 71, 94 persen, artinya mayoritas konsumen sudah merasakan puas terhadap kinerja restoran secara keseluruhan.

\section{Saran}

1. Pihak Restoran Happy Cow Steak perlu melakukan perbaikan terhadap atribut-atribut yang berada pada kuadran I yang merupakan prioritas utama agar restoran dapat meningkatkan kepuasan konsumen. Hal yang harus dirubah diantaranya adalah mengganti seluruh peralatan makan untuk steak yang sudah tidak layak, membuat jadwal piket dan penanggungjawab kebersihan harian, dan meningkatkan kenyamanan dengan menata ulang sirkulasi udara ruang indoor restoran, restoran dengan memperbaiki exhaust stove, serta menambahkan exhaust fan pada ruang indoor restauran agar dapat mengoptimalkan rasa nyaman bagi konsumen.

2. Pihak Restoran Happy Cow Steak sebaiknya tetap menyebarkan kuesioner penilaian kinerja dan kepuasan kepada konsumen secara berkala agar pihak restoran dapat mengontrol kinerja mereka, dan terus memperbaharui atribut apa yang diinginkan oleh konsumen. Restoran juga dapat menjaga kepuasan konsumen mereka dengan mengevaluasi kinerja secara rutin dengan waktu yang berkala. 


\section{DAFTAR PUSTAKA}

[BPS] Badan Pusat Statistika Kota Bogor. 2013. Kota Bogor Dalam Angka 2013. Bogor (ID): BPS Kota Bogor.

Andreani, Fransisca. 2010. Analisa Kualitas Layanan Bisnis Makanan dan Minuman di Surabaya Ditinjau dari Derajat Pemenuhan Kepuasan Konsumen. Jurnal Manajemen Pemasaran, 5: 1-8.

Alma, Buchari. 2000. Manajemen Pemasaran dan Pemasaran Jasa. Bandung : Alfabeta.

Aminu, Ahmad, Ahmad Hartini. 2008. Marketing Mix Drivers of Clients Satisfaction in Technology-enabled Service: Study of Nigerian GSM Subscribers. Communication of The IBIMA, 1: 84-90.

Ariffin, Hashim Fadzil, Mohamad Fahmi Bibon, dan Raja Puteri Saadiah Raja Abdullah. 2012. Restaurant's Atmospheric Elements: What Customer Wants. Procedia, 38: 380-387.

Baye, Michael. 2002. Managerial Economics and Business Strategy. New York: McGraw-Hill Education.

Bloemer, Odekerken-Schroder. 2002. Store Satisfaction and Store Loyalty Explained by Customer and Store Related Factors. Journal of Consumer Satisfaction, Dissatisfaction and Complaining Behaviour, 15:68-80.

Dinas Informasi Kebudayaan dan Pariwisata Kota Bogor. 2012. Data Pariwisata Kota Bogor. Bogor: BPS Kota Bogor.
Engel JF, Blackwell RD, Miniard PW. 1994. Perilaku Konsumen Edisi Keenam Jilid 1. Diterjemahkan oleh: FX Budiyanto. Jakarta: Binarupa Aksara.

Fadhila, Achmad Haris. 2010. Analisis Kepuasan dan Loyalitas Konsumen Terhadap Menu Pancake di Pantasteiik Restaurant Botani Square serta Implikasinya Terhadap Alternatif Bauran Pemasaran [skripsi]. Bogor (ID): Fakultas Ekonomi dan Manajemen, Institut Pertanian Bogor, Bogor.

Fitriani J. 2012. Analisis Tingkat Kepuasan Konsumen Terhadap Restoran Ikan Bakar dalam Bambu "Karimata" di Sentul Bogor, Jawa Barat [skripsi]. Bogor: Fakultas Ekonomi dan Manajemen, Institut Pertanian Bogor, Bogor.

Gunawan, Intan Mega Puspita. 2013. Analisis Pengaruh Kepuasan terhadap Loyalitas Konsumen Restoran Gado-Gado Boplo Kelapa Gading, Jakarta Utara [skripsi]. Bogor: Fakultas Ekonomi dan Manajemen, Institut Pertanian Bogor, Bogor.

Harianto, David, dan Hartono Subagio. 2013. Analisa Pengaruh Kualitas Layanan, Brand Image, dan Atmosfer Terhadap Loyalitas Konsumen dengan Kepuasan Konsumen sebagai Variabel Intervening Konsumen Kedai Deja$\mathrm{Vu}$ Surabaya. Jurnal Manajemen Pemasaran, 1(1): 1-8.

Hasan A. 2013. Marketing dan KasusKasus Pilihan. Jakarta (ID): Center for Academic Publishing Service. 
Hurriyati, Ratih. 2005. Bauran Pemasaran dan Loyalitas Konsumen. Bandung (ID): CV.Alfabeta.

Irawan, Deny, dan Edwin Japarianto. 2013. Analisa Pengaruh Kualitas Produk Terhadap Loyalitas Melalui Kepuasan Sebagai Variabel Intervening Pada Pelanggan Por Kee Surabaya. Jurnal Manajemen Pemasaran, 1(2): 1-8.

Istianto, John Hendra, Maria Josephine Tyra. 2011. Analisis Pengaruh Kualitas Layanan Terhadap Kepuasan Pelanggan Rumah Makan Ketty Resto. Jurnal Ekonomi dan Informasi Akuntansi, 3: 275-293.

Kotler P, Keller KL. 1997. Manajemen Pemasaran Edisi 13 Jilid 1. Diterjemahkan oleh: Bob Sabran. Jakarta (ID): Erlangga.

Mangkunegara, AA Anwar Prabu. 2002. Perilaku Konsumen. Bandung (ID): PT Refika Aditama.

Ryu, Kisang, Heesup Han. 2011. New or Repeat Customers: How Does Physical Environment Influences Their Restaurant Experience? International Journal of Hospitality Management, 30: 599-611.

Schiffman, Leon, Kanuk Leslie Lazar. 2008. Perilaku Konsumen Edisi Ketujuh. Jakarta (ID): PT Index Group.

Sumarwan, Ujang. 2002. Perilaku Konsumen. Bogor (ID): Ghalia Indonesia.
Tan, Qing qing, Ade Oriade, dan Paul Fallon. 2014. Service Quality and Customer Satisfaction In Chinese Fast Food Sector: A Proposal For CFFSERV. Avances in Hospitality and Tourism Research, 2: 30-53. 
Lampiran 1. Atribut Restoran Happy Cow Steak

\begin{tabular}{|c|c|}
\hline $\begin{array}{c}\text { Bauran pemasaran } \\
\text { (marketing } \text { mix) }\end{array}$ & Atribut \\
\hline \multirow[t]{9}{*}{ Product (Produk) } & Cita rasa steak yang enak \\
\hline & Tampilan penyajian steak (platting) \\
\hline & Porsi steak yang pas \\
\hline & Aroma yang menggugah selera \\
\hline & Variasi menu steak yang beragam dan menarik \\
\hline & Variasi menu selain steak yang beragam dan menarik \\
\hline & Variasi saos steak beragam dan menarik \\
\hline & Variasi ukuran steak beragam dan menarik \\
\hline & Kesegaran steak yang disajikan \\
\hline \multirow[t]{2}{*}{ Price (Harga) } & Harga produk yang ditawarkan \\
\hline & Kesesuaian antara harga dengan porsi atau kualitas produk \\
\hline \multirow[t]{3}{*}{ Place (Tempat) } & Kemudahan menjangkau lokasi \\
\hline & Kebersihan restoran \\
\hline & Kenyamanan restoran \\
\hline \multirow[t]{3}{*}{ Process (Proses) } & Kecepatan penyajian \\
\hline & Kecepatan transaksi pembayaran \\
\hline & Tanggapan terhadap keluhan konsumen \\
\hline \multirow[t]{4}{*}{ People (Orang) } & Keramahan pramusaji terhadap konsumen \\
\hline & Pengetahuan pramusaji terhadap menu \\
\hline & Kesigapan pramusaji dalam memenuhi pesanan \\
\hline & Penampilan pramusaji \\
\hline \multirow{5}{*}{$\begin{array}{l}\text { Physical Evidence } \\
\text { (Bukti fisik) }\end{array}$} & Desain interior restoran yang menarik \\
\hline & Kebersihan dan ketersediaan toilet \\
\hline & Kelengkapan peralatan makan Steak \\
\hline & Tampilan luar restoran \\
\hline & Ketersediaan faktor entertain (musik, tv, wi-fi) \\
\hline Promotion (Promosi) & $\begin{array}{l}\text { Ketersediaan dan kejelasan papan nama restoran } \\
\text { Promosi melalui media sosial }\end{array}$ \\
\hline
\end{tabular}


Ayumi Fitriani Gunawan, dan Wahyu Budi Priatna 